\title{
The effect of additional aluminium to the strength of geopolymer paste
}

\author{
Aulia Rahman $^{1}$ and Januarti Jaya Ekaputri ${ }^{2 *}$ \\ ${ }^{1}$ Master Student Department of Civil Engineering, ITS, Surabaya, Indonesia \\ ${ }^{2}$ Civil Engineering Department, Institut Teknologi Sepuluh Nopember, Sukolilo, Surabaya, Indonesia
}

\begin{abstract}
Alternative cementitious materials have been widely used because of the environmental issue of greenhouse gasses produced by portland cement production. A possible solution is the green concrete made from fly ash based-geopolymer paste. The natural differences of Indonesian coal ash lead to various chemical contents of fly ash. The chemical composition of alkali activated paste is also varied causing differences in the strength of the paste. Silica to alumina ratio is indicated as the greatest influencing factor to geopolymer strength. The bond among silica-alumina preserves a compact microstructure resulting in the strength. This paper proposes a $\mathrm{Si}-\mathrm{Al}$ ratio between 1.5 and 2.0 by adding a synthetic aluminium substance from some sources. Using a natural aluminium substance from other fly ashes which contain excessive amounts of $\mathrm{Al}_{2} \mathrm{O}_{3}$ was one of that efforts. The result indicated that the addition of a small amount of aluminium powder showed insignificant differences in geopolymer strength. The powder addition of up to $4 \%$ of fly ash decreased the strength by up to $60 \%$ of the original one. The methods of mixing are indicated as the trigger of lower strength because geopolymerization occurs before the fly ash is reacted with alkaline activator.
\end{abstract}

Keywords: geopolymer, strength, $\mathrm{Si}$ to $\mathrm{Al}$ ratio

\section{Introduction}

The increasing global temperature due to the greenhouse effect is a worldwide problem that must to be solved. In terms of civil engineering, one of the biggest pollutants that affects the increased release greenhouse gasses $\left(\mathrm{CO}_{2}\right)$ is the mass production of cement. [1] Unfortunately, the capacity of cement mass production keeps increasing annually by up to 345.2 Mt/yr in 2018. [2] In addition, production of one tonne of Portland cement releases 0.55 tonnes of $\mathrm{CO}_{2}$ from lime stone calcination and 0.40 tonnes of carbon-dioxide from fuel combustion. [3] Thus, the research of a portland cement substitute needs to be conducted to obtain an eco-friendly cementitious material. Fly ash is the one of the most prospective cementitious substituents because its chemical contents are relatively close to portland cement and it is an abundant material as a residual product of coal-based power plants. Physical characters of fly ash product vary in some respects such as origin material, treatment, shape, size, etc., so that the Indonesian products of fly ash also vary due to the

\footnotetext{
${ }^{*}$ Corresponding author: januarti@ce.its.ac.id
} 
differences of coal resource origin. [4-6] However, different properties of fly ash will lead to different properties of the geopolymer final products. [7]

Performance of the geopolymer substance, which is fly ash paste in this case, is related to the silica and alumina content that leads to a $\mathrm{Si}-\mathrm{Al}$ ratio. Previous research of Indonesian fly ash-based geopolymer paste stated that the optimum compressive strength corresponds to $\mathrm{Si}-\mathrm{Al}$ ratio is at the range of 1.5-2.0, then the geopolymer strength tends to decrease after the ratio reaches 2.0. [8] Theoretically, increasing the amount of silica increases the number of Si-O-Si bonds, which are stronger than the Si-O-Al and Al-O-Al bonds, which means a higher silica content corresponding to a higher strength due to the stronger bonds among the particles. [9] However, it was found that the reduction in strength for high $\mathrm{Si} / \mathrm{Al}$ ratio mixes was the result of unreacted material, so that it just acts as binder which insignificantly contributes to particle bonds. [10]

This research proposes the addition of alumina content to reduce the excessive amount of silica, so that the controlled $\mathrm{Si}-\mathrm{Al}$ ratio is obtained, close to the optimum point, which according to previous research is 1.5. The strength differences before and after the addition of alumina substance are also analysed. The performance of geopolymer paste under the effect of natural and synthetic aluminium substance addition is also compared.

\section{Methods}

\subsection{Fly ash}

Seven different fly ashes from various origins in the Java and Sulawesi islands are gathered. They are labelled as FA1 (Paiton - East Java), FA2 (Pacitan - East Java), FA3 (Jeneponto South Sulawesi), FA4 (Tanjung Jati - West Java), FA5 (Bayah - West Java), FA6 (Petrokimia - East Java), and FA7 (Suralaya - West Java). All samples were tested to obtain oxide chemical contents by using XRF (X-ray Fluorescence) analysis. [11]

\subsection{Activators}

Alkali activated was prepared by mixing sodium hydroxide $(\mathrm{NaOH})$ with the concentration of $8 \mathrm{M}$ and sodium silicate $\left(\mathrm{Na}_{2} \mathrm{SiO}_{3}\right)$ with the following chemical contents: silicate oxide $(30 \%)$, sodium oxide $(15 \%)$, and water $(55 \%) . \mathrm{NaOH}$ and $\mathrm{Na}_{2} \mathrm{SiO}_{3}$ are mixed with the proportion of 1:2.

\subsection{Aluminium powder}

Aluminium powder was selected as a synthetic additive substance. The chemical composition is predominantly aluminium, at more than $99 \%$, but it contains about $36.72 \%$ water. [12] This is a highly reactive substance that produces a huge amount of hydrogen gas.

\subsection{Geopolymer paste}

The paste itself is formed by mixing precursor and activator by a proportion of $65: 35$, then placed in the $2 \times 4 \mathrm{~cm}$ cylindrical sized mould. All of the samples are tested at the age of 7 and 28 days by using UTM (Universal Testing Machine) for speed loading of $2 \mathrm{MPa} / \mathrm{s}$.

As for the synthetic alumina substance, the research was repeated once more with the addition of aluminium powder as comparison. Figure 1 shows that the aluminium powder needs to be shaved first. Only $1 \%$ of precursor material is added, which is fly ash. The ratio of solid to solution is not changed, which is $65: 35$, and the ratio of sodium hydroxide to 
sodium silicate of activator is also not altered, which is 1:2. Synthetic aluminium powder is poured once the activator solution ready, then the redox reaction can occur to release a huge amount of hydrogen and heat. The only reason the addition of powdered aluminium is limited to about $1 \%$ of precursor material is solely to avoid the harmfulness of the redox reaction itself, and to keep the solubility of activator. However, it is only tested in the age of 7 days and 28 days as the representation of early days and final days of strength development

Two samples are selected that keep the $\mathrm{Si}-\mathrm{Al}$ ratio greater than $2.0(\mathrm{FA}+)$ and closer to 1.5 (FA-). A sample is also chosen that shows excessive alumina content as the source of natural alumina addition $\left(\mathrm{FA}_{\mathrm{Al}}\right) . \mathrm{FA}+$ and $\mathrm{FA}_{\mathrm{Al}}$ are mixed, then $\mathrm{FA}-$ and $\mathrm{FA}_{\mathrm{Al}}$ by the 50:50 mass proportion without adding any of the synthetic aluminium powder. The added aluminium samples are also tested under same condition of loading and ages. Then by adding synthetic powdered aluminium once again, the $\mathrm{Si}-\mathrm{Al}$ ratio approached that of the natural one. However, the ratio of sodium hydroxide and silicate needs to be modified because the synthetic powdered aluminium should neatly dissolve into the solution, which means the proportion of sodium hydroxide needs to be enlarged. On the other hand, the precursor to activator ratio remains unchanged, which is 65:35.

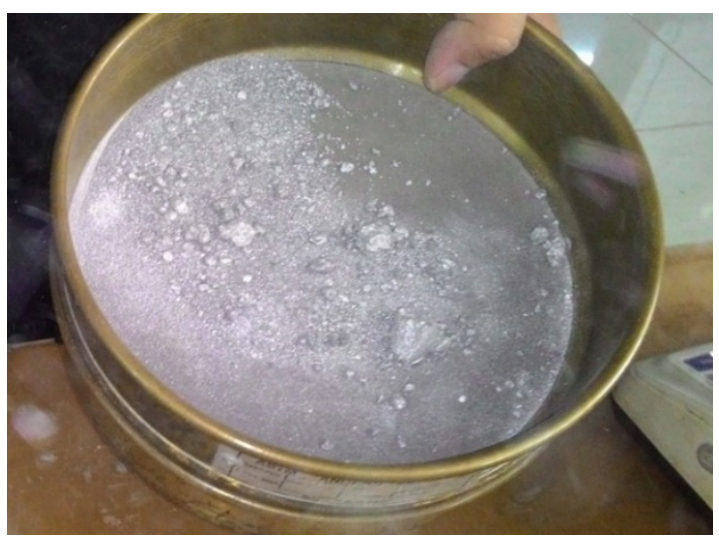

Fig. 1. The addition of synthetic aluminium substance as powder.

\section{Results and discussion}

\subsection{Alkali activated geopolymer paste}

The data of chemical oxide contents of each fly ash are obtained, as follows:

Table 1. XRF result of chemical components.

\begin{tabular}{|c|c|c|c|c|c|c|c|c|c|c|c|}
\hline \multirow{2}{*}{ Code } & \multicolumn{10}{|c|}{ Chemical content percentage per mass (\%) } \\
\cline { 2 - 14 } & $\mathbf{S i O}_{2}$ & $\mathbf{A l}_{2} \mathbf{O}_{3}$ & $\mathbf{F e}_{2} \mathbf{O}_{3}$ & $\mathbf{T i O}_{2}$ & $\mathbf{C a O}$ & $\mathbf{M n}_{2} \mathbf{O}_{3}$ & $\mathbf{M g O}$ & $\mathbf{C r}_{2} \mathbf{O}_{3}$ & $\mathbf{K}_{2} \mathbf{O}$ & $\mathbf{N a}_{2} \mathbf{O}$ & $\mathbf{S O}_{3}$ \\
\hline FA1 & 36.75 & 16.91 & 15.04 & 0.74 & 17.33 & 0.18 & 7.06 & 0.01 & 1.18 & 2.49 & 1.61 \\
\hline FA2 & 44 & 36.69 & 4.5 & 0.42 & 5.32 & 0.08 & 6.5 & 0.01 & 0.55 & 1.32 & 0.37 \\
\hline FA3 & 34.71 & 14.07 & 23.14 & 0.97 & 17.11 & 0.31 & 6.75 & 0.01 & 0.86 & 0.35 & 0.79 \\
\hline FA4 & 48.7 & 24.56 & 11.06 & 1.06 & 5.56 & 0.07 & 2.56 & 0.02 & 2.45 & 2.43 & 0.73 \\
\hline FA5 & 47.33 & 32.99 & 6.95 & 1.08 & 6.16 & 0.08 & 1.69 & 0.01 & 0.59 & 1.41 & 0.81 \\
\hline FA6 & 39.15 & 18.19 & 14.26 & 0.79 & 15.99 & 0.17 & 6.7 & 0.01 & 1.33 & 1.61 & 1.12 \\
\hline FA7 & 39.83 & 23.76 & 13.51 & 1.06 & 11.83 & 0.2 & 4.8 & 0.01 & 0.84 & 2.14 & 1.16 \\
\hline
\end{tabular}


Previous research had obtained the strength development of all samples from 3 days until 56 days of testing age. The same amount of either precursor and activator substance is used, and even the proportions are not differentiated. Figure 2 shows that the highest strength is given by FA5, and the lowest one is FA4 after 56 days of testing age. It is also shown that the sample of FA1 performs the highest strength at the early day of testing, which is 3 days. By using ASTM C $168-03$ [13] as references to classify the class of each samples, it is stated in Table 1 that FA1 is categorized as class $\mathrm{C}$, with the total amount of $\mathrm{SiO}_{2}, \mathrm{Al}_{2} \mathrm{O}_{3}$, $\mathrm{Fe}_{2} \mathrm{O}_{3}$ up to $68.7 \%$, which means it shows a higher strength at the early day of testing. [14] On the other hand, FA5 as the optimum result of compressive test shows a Si-Al ratio of 1.49 and the other samples increase gradually until 2.75 (FA3) which led to a decreasing testing result of $50 \mathrm{MPa}$ (FA4). As for FA1, at the end day of strength development, it shows slightly different lowest strengths testing results with only 50.5 MPa. This phenomenon indicate the activity of excessive Ca content that weakens the end result of strength development because of early geopolymerization processes that produce more nucleus sites at the beginning. [15]

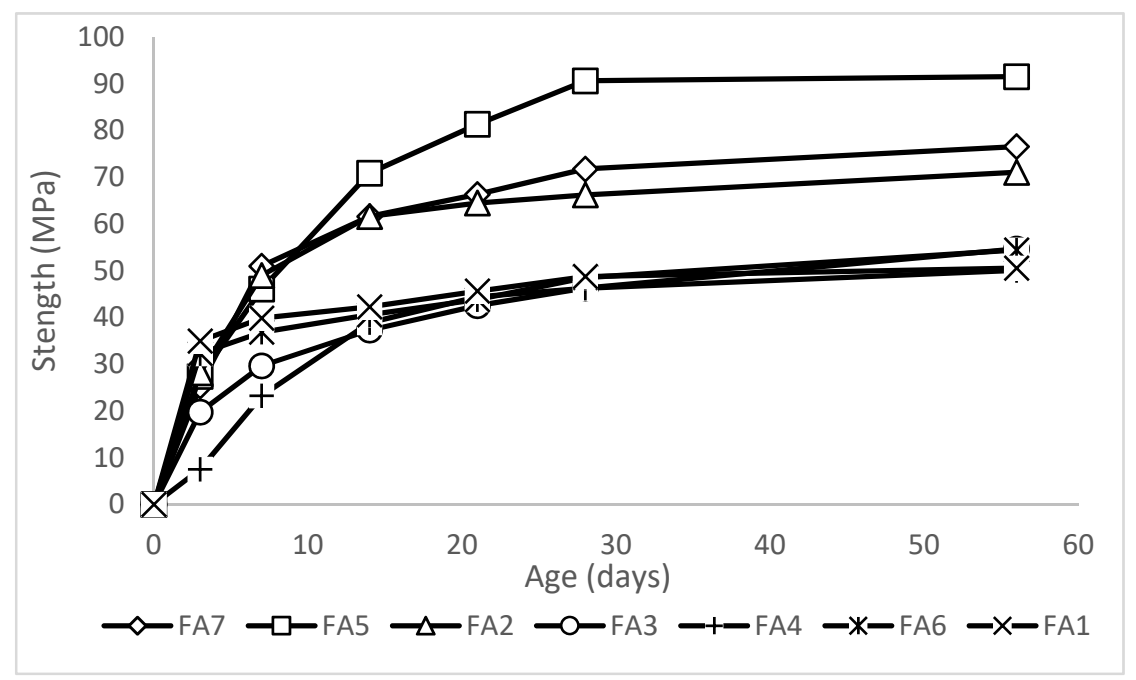

Fig. 2. Strength development each sample until 56 days of testing.

\subsection{Synthetic addition of aluminium powder}

By using Equation (1) as first step of aluminium dissolved in water, the reaction of aluminium powder in alkali solution is explained with the following exothermic reaction:

$$
2 \mathrm{Al}+6 \mathrm{H}_{2} \mathrm{O} \rightarrow 2 \mathrm{Al}(\mathrm{OH})_{3}+3 \mathrm{H}_{2} \mathrm{O}
$$

The formation of hydrogen gas in Equation (1) leads to a bubbling effect.

$$
2 \mathrm{Al}(\mathrm{OH})_{3}+\mathrm{NaOH} \rightarrow \mathrm{Na}^{+}+\left[\mathrm{Al}(\mathrm{OH})_{4}\right]^{-}
$$

In general, aluminium does not react with water. The presence of sodium hydroxide solution leads to amphoteric aluminium hydroxide, $\mathrm{Al}(\mathrm{OH})_{3}$, into solution to produce aluminates $\left[\mathrm{Al}(\mathrm{OH})_{4}\right]^{-}$in Equation (2). [6]:

Therefore, the alumina substance result should satisfy the following reaction formulation

$$
2 \mathrm{Al}(\mathrm{s})+12 \mathrm{NaOH}(\mathrm{aq}) \rightarrow 6 \mathrm{Na}_{2} \mathrm{O}(\mathrm{l})+2 \mathrm{Al}(\mathrm{OH})_{3}(\mathrm{aq})+3 \mathrm{H}_{2}(\mathrm{~g})+\text { heat }
$$


Formation of hydrogen from water in Equation (1) causes the workability of the mixture to become poor and the paste to be hard to mix. Sodium solution in Equation (3) also changes to sodium oxide leading a different alkali solution composition in the mixture.

As shown in Figure 3, there is no difference in strength results caused by synthetic aluminium powder addition. They even indicate a significant decrease in some samples, which are FA2 and FA1, especially in 28 days of testing. In the early day of testing, there are slight differences in strength such as FA7, whereas it is $44.82 \mathrm{MPa}$ for the original one, decreasing to $43.48 \mathrm{MPa}$ for the sample with powdered aluminium addition, so this insignificant difference is nearly the same due to the marginal error of data. The same effect, but with greater strength differences also occurs at 28 days of testing, such as FA3, where it is $73.05 \mathrm{MPa}$ for the original one, decreasing to $64.52 \mathrm{MPa}$ for the aluminized one. Almost every sample shows the identical effect both in the early day of testing and last day of testing, with the varied decrease of strength.

The indicated strength reduction occurs because of the disturbance of redox reaction. When the powdered aluminium is added to the mixture of activator which consists of sodium hydroxide and silicate, the alumina substance result of the chemical reaction is not considerably reactive to form a geopolymer bond.

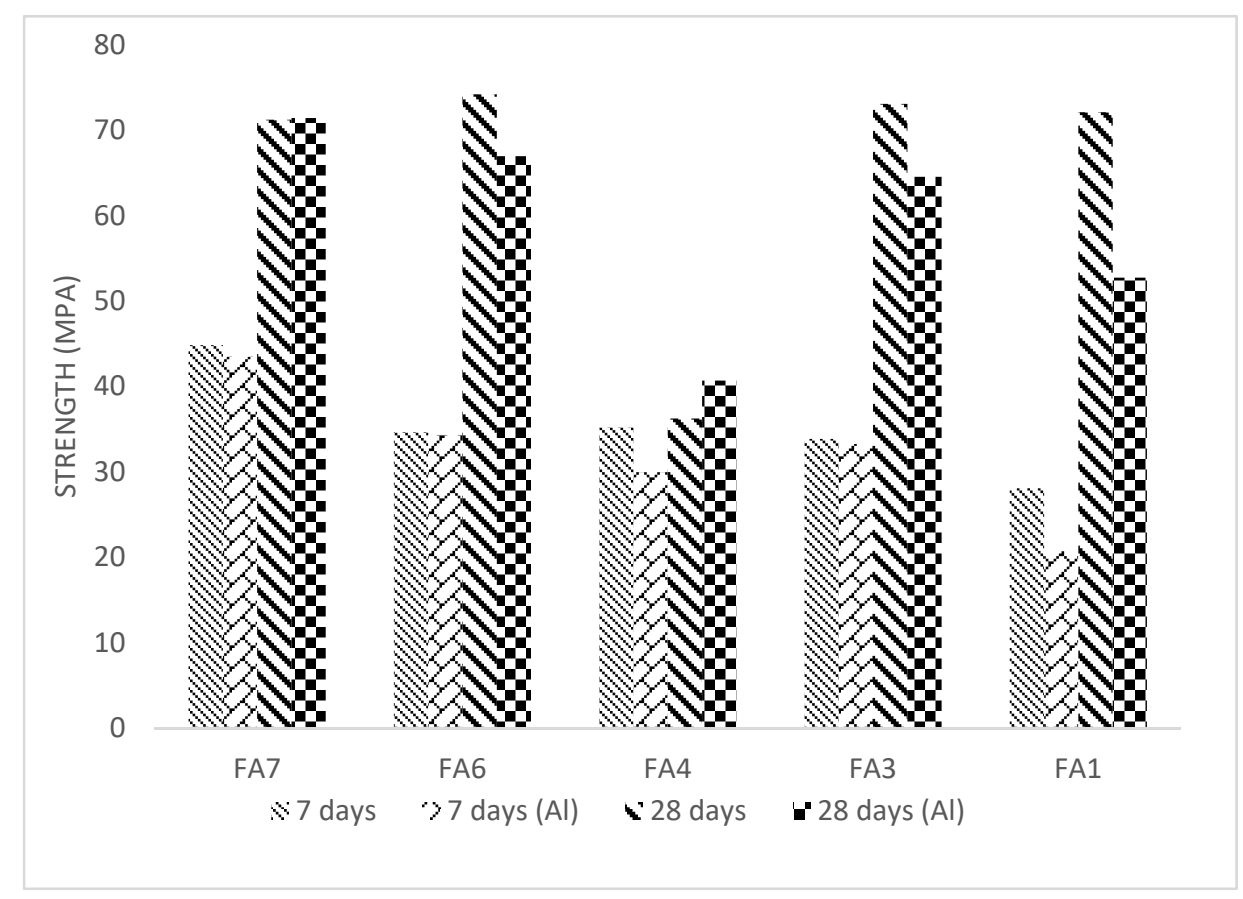

Fig. 3. Strength comparison of aluminium powder addition.

\subsection{Natural addition of aluminium substance}

According to the previous research, FA7 is selected as FA- because its $\mathrm{Si}-\mathrm{Al}$ ratio is 1.81 that means it is the closest $\mathrm{Si}-\mathrm{Al}$ ratio to 1.49 and still needs the addition of some amount of alumina substance. Actually, the $\mathrm{Si}-\mathrm{Al}$ ratio of FA2 is the closest one out of seven samples, with 1.27 . However, the aluminium oxide content of FA2 shows the highest percentage, which is $36.69 \%$, so that it is acted as $\mathrm{FA}_{\mathrm{Al}}$ or the natural aluminium substance. On the other hand, FA6 is selected as FA+ because its $\mathrm{Si}-\mathrm{Al}$ ratio is 2.33 that means it is larger than 1.49 
as the assumed optimum ratio. The $\mathrm{Si}-\mathrm{Al}$ ratio of geopolymer paste is then calculated which is mixed with 50:50 mass ratio between $\mathrm{FA}+$ to $\mathrm{FA}_{\mathrm{Al}}$ and $\mathrm{FA}-$ to $\mathrm{FA}_{\mathrm{Al}}$.

Table 2. The calculation of $\mathrm{Si}-\mathrm{Al}$ ratio under the addition of natural alumina substance.

\begin{tabular}{|c|c|c|c|c|c|c|c|c|}
\hline Code & Ratio & $\begin{array}{c}\text { Total FA } \\
\text { Mass (gr) }\end{array}$ & $\begin{array}{c}\mathrm{SiO}_{2} \\
\text { of } \mathrm{FA} \\
(\mathrm{mol})\end{array}$ & $\begin{array}{l}\mathrm{Al}_{2} \mathrm{O}_{3} \\
\text { of } \mathrm{FA} \\
(\mathrm{mol})\end{array}$ & $\begin{array}{c}\text { Activator } \\
\text { (gr) }\end{array}$ & $\begin{array}{c}\mathrm{SiO}_{2} \text { of } \\
\text { Activator } \\
\quad(\mathrm{mol})\end{array}$ & $\begin{array}{c}\mathrm{SiO}_{2} / \\
\mathrm{Al}_{2} \mathrm{O}_{3} \\
\text { total }\end{array}$ & $\begin{array}{c}\mathrm{Si} / \mathrm{Al}, \\
\text { total }\end{array}$ \\
\hline FA+ & $50 \%$ & \multirow{2}{*}{150} & 0.489 & 0.134 & \multirow{2}{*}{80.769} & \multirow{2}{*}{0.269} & \multirow{2}{*}{3.243} & \multirow{2}{*}{1.621} \\
\hline $\mathrm{FA}_{\mathrm{Al}}$ & $50 \%$ & & 0.550 & 0.270 & & & & \\
\hline FA- & $50 \%$ & \multirow{2}{*}{150} & 0.498 & 0.175 & \multirow{2}{*}{80.769} & \multirow{2}{*}{0.269} & \multirow{2}{*}{2.963} & \multirow{2}{*}{1.482} \\
\hline $\mathrm{FA}_{\mathrm{Al}}$ & $50 \%$ & & 0.550 & 0.270 & & & & \\
\hline
\end{tabular}

The new $\mathrm{Si}-\mathrm{Al}$ ratios are obtained, which are 1.62 for $\mathrm{FA}+$ and 1.48 for FA-. This means the new ratio makes them closer to the most optimum assumed $\mathrm{Si}-\mathrm{Al}$ ratio of 1.49 as stated in Table 2. Then, it is blended with another mixture by using synthetic powdered aluminium to obtain almost same $\mathrm{Si}-\mathrm{Al}$ ratio of the natural one. However, by the ratio of sodium hydroxide to sodium silicate of 1:2, it is indicated that the aluminium powder is not dissolving neatly with the sodium hydroxide due to the lack of solid to liquid ratio, and then the mixture would harden quickly. The amount of sodium hydroxide is added up so that the ratio of sodium hydroxide to sodium silicate is 3:1 for the FA- mixture and 5:1 for FA+ mixture. The addition of synthetic powdered aluminium is $3 \mathrm{gr}$ for each mixture. The addition of more than that is not suggested because of the risk of redox reaction that could harm the entire process. Table 3 shows the detailed proportion of the mixtures and the controlled $\mathrm{Si}-\mathrm{Al}$ ratios that approach the natural one.

Table 3. The calculation of $\mathrm{Si}-\mathrm{Al}$ ratio under the addition of synthetic alumina substance.

\begin{tabular}{|c|c|c|c|c|c|c|c|c|c|}
\hline Code & $\begin{array}{c}\text { Mass } \\
\text { (gr) }\end{array}$ & $\begin{array}{c}\mathrm{SiO}_{2} \\
\text { of FA } \\
(\mathrm{mol})\end{array}$ & $\begin{array}{l}\mathrm{Al}_{2} \mathrm{O}_{3} \\
\text { of } \mathrm{FA} \\
(\mathrm{mol})\end{array}$ & $\begin{array}{c}\text { Al } \\
\text { powder } \\
(\mathrm{mol})\end{array}$ & $\begin{array}{c}\text { Activator } \\
\text { (gr) }\end{array}$ & $\begin{array}{c}\mathrm{Na}_{2} \mathrm{SiO}_{3} \\
\text { (gr) }\end{array}$ & $\begin{array}{c}\mathrm{NaOH} \\
\text { (gr) }\end{array}$ & $\begin{array}{c}\mathrm{SiO}_{2} \text { of } \\
\text { Activator } \\
(\mathrm{mol})\end{array}$ & $\begin{array}{c}\mathrm{Si}- \\
\text { Al, } \\
\text { total }\end{array}$ \\
\hline $\mathrm{FA}+$ & 200 & 1.31 & 0.36 & 0.11 & 107.69 & 17.95 & 89.74 & 0.09 & 1.69 \\
\hline FA- & 400 & 2.66 & 0.93 & 0.11 & 215.38 & 53.85 & 161.54 & 0.27 & 1.48 \\
\hline
\end{tabular}

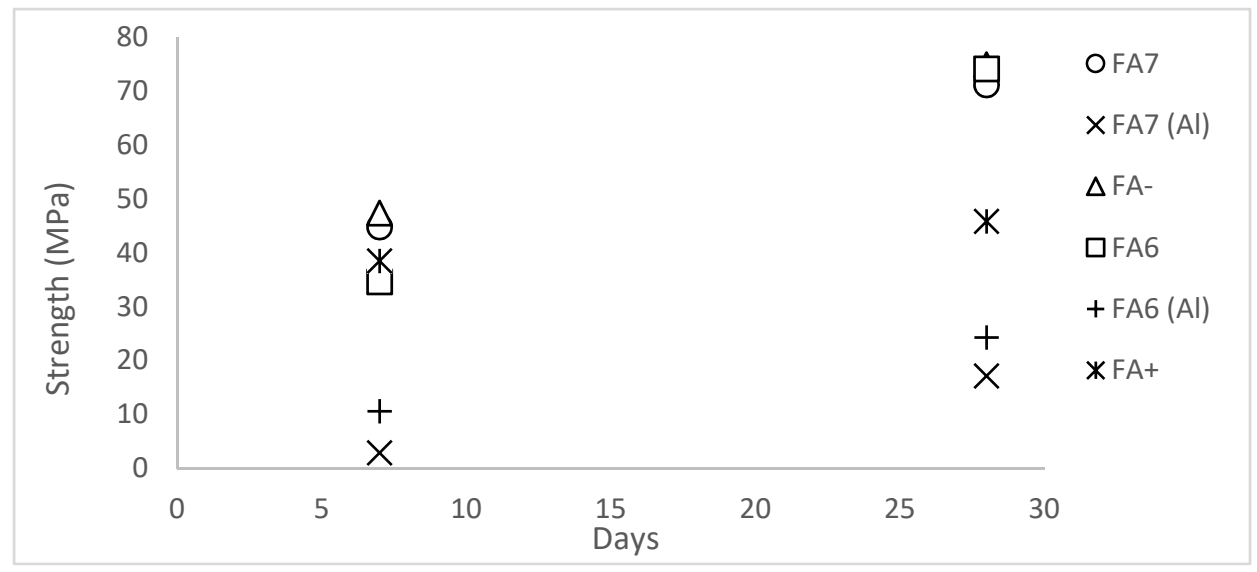

Fig. 4. The strength comparison for each sample.

Figure 4 show the strength differences under 7 days of testing and 28 days of testing. The natural aluminium substance addition shows a significantly better performance than the 
synthetic one. Although the strength differences are not too big relative to the original one, the natural aluminium additions still increase the strength in every condition. However, the compressive strength of FA+ at the 28 days of testing $(45.87 \mathrm{MPa})$ is somehow weaker than the original one $(74.19 \mathrm{MPa})$, that is the only abnormality in this research. Unfortunately, the strength of each of the synthetic aluminized samples show the worst results. There are also big gap differences between the synthetic samples and the original samples. Seemingly, the cause of this effect is the decrease of sodium silicate. Every mixture lacks a big amount of silicate due to the adjustment of the activator ratio. Even the sodium hydroxide to sodium silicate ratio is overturned with 3:1 and 5:1. While the geopolymer paste lacks a big amount of silicate, the synthetic aluminium substance is not involved in the geopolymeric reaction to form geopolymer bonds so that the loss of strength occurs.

\section{Conclusions}

The addition of aluminium substance in order to alter $\mathrm{Si}-\mathrm{Al}$ ratio shows different result in geopolymer paste strength. Addition of $1 \%$ synthetic powdered aluminium of total precursor material mass has a lesser contribution to the strength. After the 7 days of testing, strength differences between alkali activated geopolymer paste and added synthetic aluminium geopolymer paste reach less than 10\%, except for FA4. However, at the 28 days of testing, the strength differences grow bigger, but the added synthetic aluminium geopolymer paste strength is still lower than the original one, except for FA4. On the other hand, the addition of natural aluminium substance shows better results in paste strength, although it is also insignificant. Still, other samples that are mixed by using synthetic aluminium give the worst result compared to natural one. It is indicated that a reduction of silicate solution affects the strength more dominantly rather than the addition of aluminium substance, even though they shared almost the same $\mathrm{Si}-\mathrm{Al}$ ratio to the natural one.

\section{References}

1. E. Gartner, Industrially interesting approaches to "low- $\mathrm{CO}_{2}$ " cements, Cement and Concrete Research, 34(9), 1489-1498, (2004)

2. Global Cement Directory Report, (2018)

3. Davidovits. J, Global Warming Impact on the Cement and Aggregates Industries, World Resource Review, 6(2), 263-278, (1994)

4. J.J. Ekaputri, M.B. Ulum, Triwulan, R. Bayuaji, T.E. Susanto, M.M.A.B. Abdullah, A Comprehensive Characterization and Determination of Fly Ashes in Indonesia using Different Methods AMM, 754-755, 320-325, (2015)

5. N. Ratni, J.J. Ekaputri, M. Bahrul Ulum, Triwulan, P. Suprobo, Characterization of Fly Ash on Geopolymer Paste

6. J. J. Ekaputri, Triwulan and T. E. Susanto, Lightweight Geopolymer Paste made with Sidoarjo Mud, the 6th ACF 2014, 1053-1057, (2014)

7. Wattimena1, Oswyn., S.W. Antoni., Hardjito, Djwantoro, A Review on the Effect of Fly Ash Characteristics and Their Variations on the Synthesis of Fly Ash Based Geopolymer, AIP Conference Proceedings 1887, 020041; doi: 10.1063/1.5003524, (2017)

8. L. Wijaya, Adhitya, J.J. Ekaputri, Triwulan, Factors influencing strength and setting time of fly ash based-geopolymer paste, MATEC Web of Conferences, 138, 01010, (2017)

9. J. Davidovits, Geopolymers - Inorganic polymeric new materials, Journal of Thermal Analysis, 37(8), 1633-1656, (1991) 
10. S. Komarneni, R. Roy, D.M. Roy, C.A. Fyfe, G.J. Kennedy, A.A. Bothner-By, J. Dadok, and A.S. Chesnick, 2729A1 and Si magic angle spinning nuclear magnetic resonance spectroscopy of Al-substituted tobermorites: J. Mat. Sci. 1985(20), 4209-4214, (1985)

11. American Society for Testing and Materials, Standard Test Method for Major and Minor Elements in Coal and Coke Ash By X-Ray Fluorescence, ASTM D 4326 - 11, in Annual Book of ASTM Standard, (2004)

12. K. Dwi Wulandari, J.J. Ekaputri, An Investigation of Damage Factors in Industrial Scale of Light-Weight Bricks Production, MATEC Web of Conferences, 138, 01018, (2017)

13. American Society for Testing and Materials, Standard Specification for Coal Fly Ash and Raw or Calcined Natural Pozzolan for Use in Concrete, ASTM C 168, in Annual Book of ASTM Standard, (2004)

14. S.W. Antoni, D. Wijaya, Hardjito, Djwantoro, Factors Affecting the Setting Time of Fly Ash-Based Geopolymer, Mater. Sci. Forum, 841, 90, (2016)

15. S. Pangdaeng, et al., apatite forming on calcined kaolin-white Portland cement geopolymer, Mater Sci Eng, C 2015, 51(1-6), (2015) 